\title{
Design of PWM-Based Photo Irradiation System for Acne Treatment
}

\author{
Changsu Kim****, Hyunsoo Lim ${ }^{* *}$ \\ Department of Biomedical Engineering, Konyang University Hospital , Department of Biomedical Engineering, Chungnam National University ${ }^{* *}$
}

\author{
여드름 치료를 위한 PWM 기반 광 조사 시스템 설계 \\ 김창수 ${ }^{* * *}$, 임현수** \\ 건양대학교병원 의공학과*, 충남대학교 의과대학 의공학과**
}

\begin{abstract}
As one of photo dynamic therapies, the existing LED photo irradiation method with $635 \mathrm{~nm}$ continuous wave has most frequently been used for acne treatment, it suffered from a low energy efficiency and generation of a large amount of heat in tissues requiring improvement measures. In this thesis, a LED photo irradiation system for acne treatment has been designed using PWM(Pulse Width Modulation) mode to enhance the energy efficiency and prevent thermal destruction in tissues. System configuration consisting largely of timer module, PWM module, and photo transfer device has been designed with the use of $1 \mathrm{~W}$ LED at a wavelength of $660 \mathrm{~nm}$ for the photo transfer device to increase skin penetration depth for treatment of acne. Frequency and wave form generated by using PWM control was verified along with confirmation of output energy of 660 $\mathrm{nm}$ LED and surface temperatures of tissues, followed by evaluation of stable energy outputs and stability of tissues. The results indicated that whereas power loss was high and thermal destruction in tissues was exhibited when C.W mode was used to obtain the optical energy of $1 \mathrm{~W}$ LED at a wavelength of $660 \mathrm{~nm}$ for acne treatment, realization of PWM mode allowed lowering of power consumption for LED through pulse width modulation, and no occurrence of thermal destruction in tissues, suggesting that PWM mode is safer and more effective for treatment of acne than C.W mode.
\end{abstract}

Key words: 660nm LED, PWM, Photo Transfer Device, Acne

\section{요야}

광 역학치료(Photodynamic therapy: PDT) 중 하나인 기존의 LED 광 조사는 연속파(Continuous wave: C.W) 방식 의 $635 \mathrm{~nm}$ 파장으로 여드름 치유에 가장 많이 사용되어 왔으나, 이 방식은 에너지효율이 낮고 생체조직에 열이 많이 발생하여 개선의 방안이 필요했다. 본 논문에서는 에너지효율을 높이고 여드름 치료를 위하여 생체조직에서의 열적 파 괴현상을 방지하기위해 PWM(펄스 폭 변조: Pulse Width Modulation)을 활용한 여드름 치료용 LED 광 조사장치를 설계하였다. 시스템 구성은 크게 Timer 모듈, PWM 모듈, 광학전달 장치로 크게 세구성하여 설계하였으며, 여드름 치 료를 위한 피부 투과 깊이를 높이기 위하여 광학전달 장치는 $660 \mathrm{~nm}$ 파장의 $1 \mathrm{~W} \mathrm{LED}$ 를 사용하였다. PWM 제어를 이용하여 발생된 주파수와 파형을 확인하고, $660 \mathrm{~nm} \mathrm{LED}$ 의 출력에너지 및 생체조직의 표면온도를 확인하여 안정적인 에너지출력과 생체조직의 안정성에 대해 평가하였다. 그 결과 여드름 치료를 위한 $660 \mathrm{~nm}$ 파장의 $1 \mathrm{~W} \mathrm{LED}$ 광 에너 
지를 얻기 위하여 C.W 방식으로 사용하였을 경우 전력손실이 높고 생체조직에서의 열적 파괴현상을 보였으나, PWM 방식을 구현함으로써 펄스 폭 변조를 통하여 LED의 전력소모를 낮추었고, 생체조직의 열적 파괴현상이 나타나지 않아 여드름 치료를 위해 사용할 경우 C.W 방식보다 PWM 방식이 더 안전하고 효과적일 것으로 사료된다.

중심단어: $660 \mathrm{~nm}$ 파장 $\mathrm{LED}$, 펄스 폭 변조, 광학전달 장치, 여드름

\section{I. 서론}

피부질환 치료용 치료기기로는 레이저와 LED를 이 용한 광 역학치료법이 많이 사용되어지고 있다. 광 역 학치료(Photodynamic therapy: PDT)란 특정 파장에 반 응하는 광감작제를 체내에 주입하거나 혹은 체외에 도피 후 특수한 파장을 가진 빛으로 그 물질을 활성화 시켜 광화학적, 광생물학적 작용으로 암세포를 괴사 시키는 방법이다 ${ }^{[1]}$. 초기에 광 역학치료법은 암 치료 를 위해 고안되었으나, 적절한 광감작제의 선별을 통 하여 피부 질환 치료에 응용하는 경우, 피부 내부에 존재하는 불필요한 세포조직을 제거함으로써 피부질 환을 치료할 수 있다 ${ }^{[2]}$. 광 역학치료의 적용가능 질환 은 피부 $\mathrm{T}$ 세포림프종(cutaenous T-cell lymphoma), 여드 름(acne vulgaris), 혈관종(vascular tumor), 건선(psoriasis), lichen sclerosis, 편평태선(lichen planus), 강피증 (scleroderma), 피부레쉬마니아증(cutaneous leishmaniasis) 등이 있으며, 그 중 여드름 치료에 중점을 두고 시스템 설계를 하였다.

여드름은 털 피지샘 단위(Pilosebaceous unit)의 만성 염증성 질환으로 피부과에 내원한 환자들에서 흔히 볼 수 있는 질환이다 ${ }^{[3]}$. 여드름의 치료에 있어 약물, 레이저와 빛 등 여러 가지가 있으나 이런 다양한 방법 중 최근 $\mathrm{LED}$ 광원을 이용한 방법이 대두되고 있다.

$\mathrm{LED}$ 는 전기 신호를 빛으로 방출하는 반도체 소자 로서 소형, 경량, 저전력, 저발열 및 고속 응답성 등의 특성과 장점을 지니고 있다. 특히, 전류에 따라 광 출 력의 제어가 용이하고 제작공정 및 재료의 발달로 다 양한 빛을 발현할 수 있어 디스플레이 및 각종 백라이 트 등 여러 분야에서 활용되어지고 있음 ${ }^{[4],[5]}$ 은 물론 $\mathrm{LED}$ 를 이용한 의료분야의 적용은 이미 다양하게 연 구되어지고 있다. $\mathrm{LED}$ 는 저출력 레이저와 같이 특정 파장의 빛을 방출하며 열에 의한 손상이나 파괴현상
이 없어 레이저보다 안전하고, 클레드 층 재료의 혼합 비 변화에 따라 다양한 파장의 빛을 발생시킬 수 있다.

의료용으로 LED 광원은 고출력 레이저가 국소적인 면적에 집중적으로 치료하는 것과 달리 적절한 광 출 력으로 넓은 면적의 질환 부위를 효과적으로 치료할 수 있다 ${ }^{[6]}$. 기존에 사용하고 있는 $635 \mathrm{~nm}$ 대역의 광 파 장은 주로 대식세포에 영향을 미치는데 대식세포는 섬유모세포의 증식과 성장인자의 생산을 증가시켜 세 포외기질의 재형성을 유도하는 장점이 있지만, $660 \mathrm{~nm}$ 대역의 파장은 피지생성 억제효과, 염증반응의 소실 및 콜라겐의 합성 증가 등으로 효능이 있으며 염증성 병변을 가진 구진과 농포, 여드름 치료에 효과가 있는 것으로 보고되고 있다 ${ }^{[7][8]}$.

이에 본 논문에서는 섬유모세포(Fibroblast)에서부터 망상진피(Reticular dermis)까지 효과를 발휘할 수 있는 $660 \mathrm{~nm}$ 파장대역과 광 역학치료를 위한 $1 \mathrm{~W}$ LED를 사용하였고 ${ }^{[9],[10]}$, 불필요한 전력낭비를 감소하고 생체 조직의 열적특성을 관찰하기위해 $\mathrm{PWM}($ 펄스 폭 변조: Pulse Width Modulation) 제어를 통한 고효율 LED 광 조사 시스템을 설계하였다. 그리고 설계되어진 $\mathrm{LED}$ 광 조사 시스템을 이용하여 $\mathrm{LED}$ 의 출력세기 및 에너 지 변화를 확인하였으며, 기존의 C.W 방식과 PWM 방 식을 비교·분석하여 안정적인 에너지 출력과 조직 (Tissue)에서의 열적반응에 대해 평가하였다.

\section{II. 본론}

\section{1. 시스템 구성}

여드름치료를 위한 광 조사 장치를 효과적으로 여 기시키기 위해서는 충분한 출력에너지와 빛의 파장대 를 가져야하고 전반적인 구동장치의 회로방식에 따라 전체 소비전력과 특성의 차이가 나므로 효율적인 설 
계가 필요하다.

본 시스템에서는 여드름 치료에 적용할 수 있도록 개발한 $\mathrm{LED}$ 광 조사 시스템으로 사용자가 원하는 출 력의 세기, 치료시간을 입력할 수 있는 인터페이스, 모 든 시퀀스를 제어하는 중앙처리장치, 설정 된 출력을 안정적인 주파수로 변환해주는 PWM 모듈, 시스템의 전원과 방사모드를 실현하는 전원 공급 장치, 최종 출 력된 광을 전달하는 광학 전달 장치 등을 설계하였다 (Fig. 1).

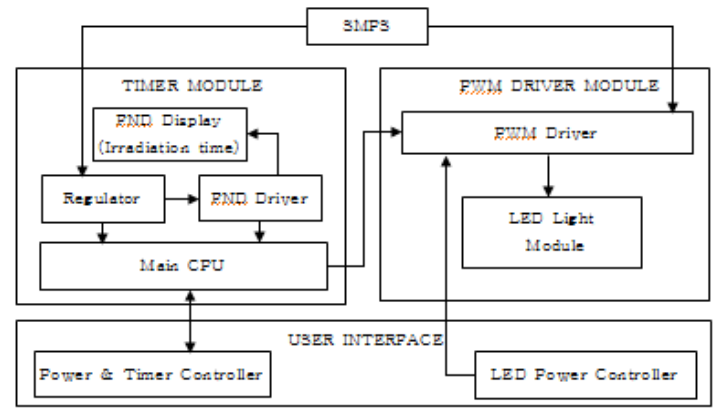

Fig 1. System block diagram

회로는 Common anode type으로, $220 \mathrm{~V}$ 교류전원을 SMPS (Switching mode power supply)로부터 공급받아 안정된 $12 \mathrm{~V}$ 직류전원으로 변환한 후 $\mathrm{PWM}$ driver module에 공급하며, $\mathrm{CPU}$ 및 구동전압이 낮은 IC는 레 귤레이터를 사용하여 $12 \mathrm{~V}$ 에서 $5 \mathrm{~V}$ 로 강압하여 회로 내부로 인가된다. 파워와 타이머컨트롤러는 기기에 전 원을 인가해주고, 사용자의 선택에 따라 시간 조정이 가능하도록 메인CPU에 시간제어 신호를 입력 시키는 부분으로 4 개의 제어신호가 입력된다. 본 기기에 사용 된 메인CPU는 $\mathrm{PIC} 16 \mathrm{C} 72 \mathrm{~A}$ 로 프로그램이 내장되어 있 어 I/O 라인을 통해 해당 모듈의 On/Off, LED 광 모 듈의 출력 시간을 표시해주는 FND (Flexible Number Display)등의 전반적인 제어가 가능하도록 구성하였다. 기기의 핵심 부분 중 하나인 PWM 드라이버는 주기가 일정한 펄스 신호의 도통 폭을 조절하여 전체 출력량 을 조절하는 Step-down, 즉 buck형 PWM LED 드라이 버를 채용하였으며, 연속파로 인가 된 파형을 PWM 파 형으로 변조시키기 위해 AMC7150을 사용하였다. LED 광 모듈부는 $660 \mathrm{~nm} 1 \mathrm{~W}$ RED High Power LED를 사 용하여 장파장이 출력되도록 구성하였다.

\section{1 타이머 시스템 설계}

타이머 시스템 모듈에서 핵심부품인 CPU는 RISC (Reduced Instruction Set Computer) 구조인 PIC16C72A 를 사용하였다. RISC 구조는 다양한 종류의 명령어들 을 제공하는 일반 마이크로프로세서와 달리 고속의 몇 가지 명령어들만을 사용하는 중앙처리장치를 사용 하여 실행속도와 소비전력 면에서 뛰어난 효과를 발 휘한다. 본 타이머 시스템은 $5 \mathrm{~V}$ 의 입력전압이 $\mathrm{CPU}$ 를 거쳐 $\mathrm{MC} 14511$ 과 $\mathrm{ULN} 2004 \mathrm{IC}$ 로 $\mathrm{CPU}$ 의 출력 신호가 입력된다. 신호가 입력된 FND 구동용 IC인 MC14511 과 $\mathrm{ULN} 2004 \mathrm{IC}$ 는 $\mathrm{FND}$ 에 조사시간을 표시해 주고 시 스템의 전반적인 POWER, Start/Stop 및 TIME $\mathrm{Up} /$ Down을 컨트롤할 수 있게 해 준다.

타이머 시스템 회로도를 다음 그림에서 나타내었다 (Fig. 2).

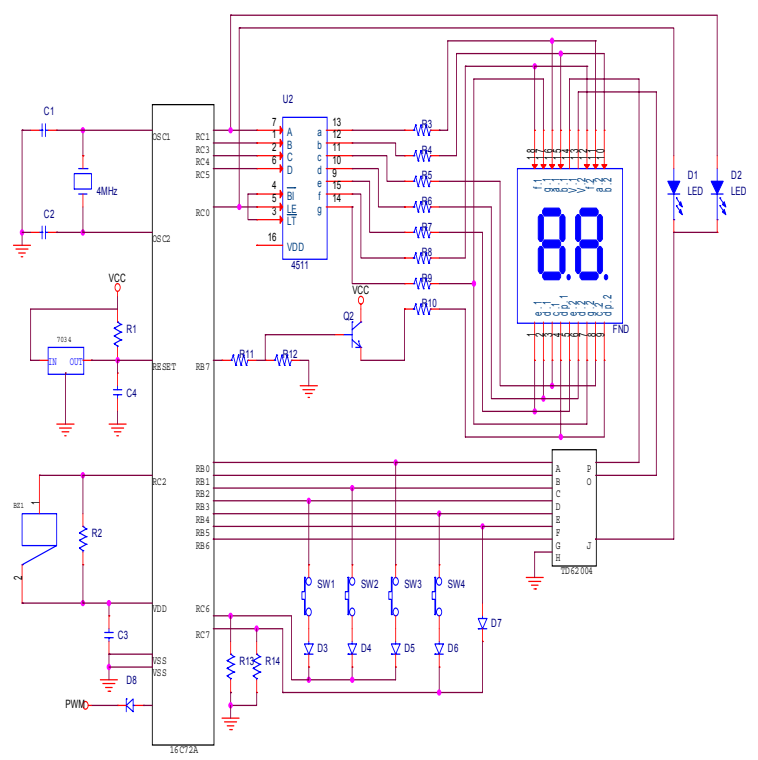

Fig 2. Timer control circuit

\section{$1.2 \mathrm{PWM}$ 시스템과 $\mathrm{LED}$ 광 모듈 설계}

PWM은 시리즈방식의 연속제어에 비해 전력낭비를 줄일 수 있으며, 회로구현이 쉽고, 듀티비(Duty ratio)에 비례하는 선형적인 전류와 전압의 출력을 기대할 수 있기 때문에 제어성 측면에서 편리하다 ${ }^{[11]}$.

$\mathrm{PWM}$ 드라이버 모듈에서는 $\mathrm{AMC} 7150 \mathrm{CPU}$ 를 사용 
하여 $\mathrm{DC} 12 \mathrm{~V}$ 의 입력전압을 공급받아 전력손실 방지 와 안정적인 출력 그리고 $\mathrm{LED}$ 에서 방출되는 열로 인 한 조직의 열적 손상을 방지하기위해 PWM 방식을 구 현하였다(Fig. 3).

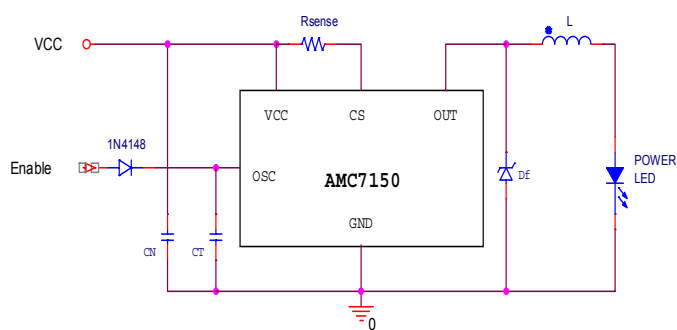

Fig 3. PWM control circuit

$\mathrm{AMC} 7150$ 은 발진기(OSC)가 만들어 낸 일정한 주파 수 구형파 신호의 도통 펄스 폭을 비교기의 출력으로 조절하여 출력 소자의 On-Off를 제어하는 내부구조를 가지고 있다. 이 회로의 핵심은 출력에 있는 인덕터 $\mathrm{L}$ 에 흐르는 전류의 상단부가 삼각파라는 원리에 근거 하고 있다. 균일한 전류가 흐르는 저항과는 달리 인덕 터는 구형파 입력이 가해지면 전류가 0 으로부터 서서 히 증가하다가 포화상태에 이르면 자기특성은 사라지 고, 동선의 저항 특성만 남아 갑자기 전류가 상승하게 된다. 인덕터 $\mathrm{L}$ 에 흐르는 이러한 삼각파 전류 중에서 상승하는 쪽의 톱날파는 $\mathrm{AMC} 7150$ 을 통해 공급받고, 하강하는 톱날파는 $\mathrm{Df}$ 를 통해 들어온다. 상승하는 톱 날파가 입력측에 있는 Rsense 저항을 통과할 때, 발생 되는 전압이 $300 \mathrm{mV}$ 를 넘게 되면 비교기가 이를 검출 하여 출력 전압을 Off 시킴으로써 전압량이 제어되며, 일정시간 후에는 발진기(OSC)에 의해 다시 $\mathrm{On}$ 되므로 이 같은 동작을 반복함으로써 전력소모를 줄이고 $\mathrm{LED}$ 의 부하를 줄일 수가 있다. 출력 전압이 Off 되었 을 때의 순간은 인덕터(L)의 주 특성인 관성의 성질로 인하여 인덕터(L)의 스위치 동작으로 전류가 흐르다가 Off되더라도 전류가 Df를 지나 LED로 계속 흐르기 때문에 $\mathrm{LED}$ 는 항상 $\mathrm{On}$ 상태를 유지할 수 있다. 결과적 으로 LED에 흐르는 전류는 깨끗한 직류가 아니라 약 $200 \mathrm{KHz}$ 삼각파가 상당량 섞여있는 리플파이지만 주 파수가 높아 눈으로는 인식할 수 없다.

$\mathrm{LED}$ 광 모듈은 $660 \mathrm{~nm}$ 의 파장대역과 최대 $1 \mathrm{~W}$ 의 빛을 방출할 수 있는 $\mathrm{LED}$ 를 적용하였으며, 전원 및
주변온도에 의해 특성이 변화되는 소자로 $3 \mathrm{~mA} 1500$ $\mathrm{mA}$ 정도의 고 전류로 동작한다. 고 전류로 동작하기 위해서는 열 저항(Thermal resistance)이 작아야 하는데 열 저항은 해당 전력에 대한 온도차의 비율로 정의되 며 단위는 $\left[{ }^{\circ} \mathrm{C} / \mathrm{W}\right]$ 로 나타낸다 ${ }^{[12]}$.

열 저항은 아래와 같은 방정식으로 나타낼 수 있다.

$R \theta_{\text {접합-주변 }}=\frac{\triangle T_{\text {접합-주변 }}}{P_{d}}$

여기서,

$$
\begin{aligned}
R \Theta & =\text { 열저항 }(\text { 접합 }- \text { 주변 }) \\
\triangle T & =T_{\text {접합 }}-T_{\text {주변 }}\left[{ }^{\circ} \mathrm{C}\right] \\
P_{d} & =\text { 소모되는 전력 }(W) \\
& =\text { 순방향 전류 }\left(I_{f}\right) \times \text { 순방향 전압 }\left(V_{f}\right)
\end{aligned}
$$

LED에서 발생하는 열에 의한 손상을 방지하기 위 해 방열판을 사용하였으며, 집광렌즈를 이용하여 빛 퍼짐 현상을 방지하였다.

완성된 여드름 치료를 위한 PWM 기반 광 조사 시 스템을 다음 그림에 나타내었다(Fig. 4).

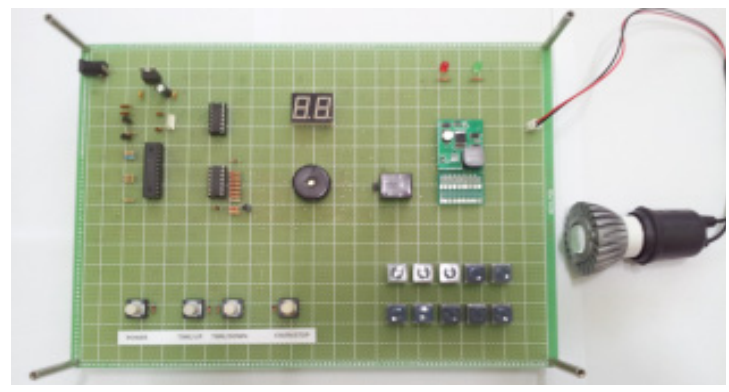

Fig 4. Developed PWM-based photo irradiation system

III. 실험기기 및 방법

\section{1. 실험기기}

\section{1 레이저 광 에너지·파워 미터}

레이저 에너지·파워 미터는 COHERENT 社의 FieldMaxII 모델로 출력 광을 전기신호로 변환하여 레 
이저나 $\mathrm{LED}$ 에서 발생하는 광의 세기를 측정하는 장 비로서, 단위는 $[\mathrm{mW}],[\mathrm{W}]$ 로 표시된다.

\section{2 디지털 멀티미터}

전류, 전압, 온도를 측정 하기위해 FLUKE 社에서 출시한 $87 \mathrm{~V}$ 모델의 디지털 멀티미터를 사용하였다. $0.05 \%$ 기본 DC 전압정확도와 주파수를 측정할 수 있 는 기능을 가지고 있으며, 인버터와 전기적인 노이즈 를 발생하는 장비의 정확한 측정을 위한 로우패스필 터기능을 탑재하고 있다.

\section{3 오실로스코프}

PWM 파형으로 변환되어 LED 광 모듈에서 발생되 는 주파수의 수치와 파형을 측정하기위한 오실로스코 프는 Tektronix 社의 TDS1012 모델을 사용하였다. 장비 의 특징은 $100 \mathrm{MHz}$ 대역폭, 최고 $1 \mathrm{GS} / \mathrm{s}$ 샘플링 속도, Dual time base 및 Triggering 기능을 가지고 있다.

\section{4 직류 전원 공급 장치}

광 조사 시스템의 직류전원을 공급하기위하여 Tektronix 社의 LP-303DU 모델을 사용하였고, 전압은 $\mathrm{DC} 0 \sim 60 \mathrm{~V}$, 전류 $0 \sim 3 \mathrm{~A}$ 까지 공급해 줄 수 있는 장치 이다.

\section{2. 실험방법}

\section{1 빛의 세기 $(\mathrm{W})$ 에 따른 출력 전압 $(\mathrm{V})$ 비교}

본 실험은 $\mathrm{PWM}$ 방식을 이용하여 $\mathrm{LED}$ 광원장치의 에너지 효율을 알아보기 위해 C.W 모드와 비교 분석 했다. C.W 모드와 PWM 모드에 $660 \mathrm{~nm} 1 \mathrm{~W} \mathrm{LED}$ 광 원장치를 연결하여 빛의 세기 $(\mathrm{W})$ 를 측정하였으며, 측 정 장비로는 COHERENT 社의 FieldMaxII 레이저 에 너지·파워 미터를 이용하였다. 두 가지 모드(C.W, $\mathrm{PWM})$ 에서 동일한 빛의 세기 $(\mathrm{W})$ 가 발생되었을 때 $\mathrm{LED}$ 광 모듈 출력 단에 발생하는 출력전압 $(\mathrm{V})$ 을 측정 하기위해 FLUKE 社의 $87 \mathrm{~V}$ 디지털 멀티미터와 Tektronix 社의 TDS1012 오실로스코프를 사용하여 C.W 모드와 PWM 모드에서 LED 광 성능을 확인했다. 먼저, 동일한 조건에서 실험을 하기 위해 $\mathrm{DC} 12 \mathrm{~V}$
를 공급받아 동작하는 PWM 모듈 입력 단에 C.W 회로 를 구성하였다. C.W 방식은 전압이 동일하게 발생되 는데 반해, PWM 방식은 전압의 On-Off 상태를 반복 적으로 발생시키기 때문에 듀티비가 발생한다. 이 듀 티비의 효율만큼 에너지 효율이 좋아지게 되는데, 이 를 확인하기 위해 동일한 조건하에 C.W 모드와 PWM 모드를 비교하였다. 이 시스템은 PWM에서 발생하는 듀티비로 인하여 전압의 세기가 바뀌게 되어 동일한 빛의 세기 $(\mathrm{W})$ 와 전류(A)가 흐를 때 디지털 멀티미터를 이용하여 두 가지 모드의 출력전압 $(\mathrm{V})$ 을 비교하여 에 너지효율을 확인하였다. LED에서 발생하는 빛의 세기 를 측정하기 위한 광 에너지·파워미터는 주위환경의 영향을 많이 받는 장비로서 빛이 들어오지 않는 암실 에서 주위온도 $25{ }^{\circ} \mathrm{C}$ 를 유지하고 측정하였다.

\section{$2.2 \mathrm{LED}$ 광 에너지에 의한 생체조직 열적 영향}

$\mathrm{PWM}$ 모듈에서 신호를 받은 LED의 출력파형을 확 인하기위하여 LED 광 모듈에 Tektronix 社의 TDS1012 오실로스코프를 이용하여 주파수의 흐름을 측정하였 다. 그리고 LED 빛의 출력모드의 변화에 따른 생체조 직의 열적변화를 확인하기위해 돼지고기의 목살(Jowl) 을 이용하여 두 가지 출력 모드로 빛을 조사하였다. 생체조직에 대한 방사모드의 열적평가를 위해 돼지목 살 $3 \mathrm{~mm}$ 깊이에 온도 센서를 삽입하여 $660 \mathrm{~nm} 1 \mathrm{~W}$ $\mathrm{LED}$ 로 빛을 조사했다. 실제 빛의 파워밀도는 950 $\mathrm{mW} / \mathrm{cm} 2$ 이며, 총 에너지량 $1000 \mathrm{~J} / \mathrm{cm} 2$ 로 각각 주입하 였다.

빛 에너지를 확인하기위해 광 에너지·파워미터를 사용하여 얻어낸 빛의 세기(W) 값을 아래 de Broglie 관계식에 의거한 에너지 공식에 대입하여 에너지 값 을 산출하였다.

$$
\begin{aligned}
E= & h v(v: \text { 진동수, } h: \text { 플랑크 상수 }), \\
& v=\frac{c}{\lambda}(\lambda: \text { 파장 }) \\
& h: 6.62619 \times 10^{-34} \text { J.s }
\end{aligned}
$$

단위, $W=J / s$ or $e V$, ( $J$ : 에너지, $s: 1 / \mathrm{sec}$ )

$$
\therefore J=s \times W
$$


광이 조직내부로 입사될 때, 조직 내부에서 광의 영향율은 지수적으로 감소하게 된다(Beer's law).

조직 안에서 감쇠된 광 C.W 모드일 때와 PWM 모 드일 때 Beer's의 법칙은 동일하게 성립한다. 조직 내부 의 깊이 $\mathrm{z}$ 에서 감쇠된 광의 단위 면적당 에너지 $\mathrm{H}(\mathrm{z})$ 는 다음과 같이 나타낼 수 있다 ${ }^{[13]}$.

$$
H(z)=\left(1-r_{s}\right) H_{0} e^{-\mu_{t} z}
$$

여기서, $\mathrm{H} 0$ : 방사노출량 $[\mathrm{J} / \mathrm{m} 2]$

$\mathrm{H}(\mathrm{z})$ : 조직내 거리(z 지점에서 LED 광의

단위 면적당 에너지).

\section{3. 실험결과}

\section{1. 빛의 세기 $(\mathrm{W})$ 에 따른 출력전압 $(\mathrm{V})$ 비교 결과}

PWM 모듈에서 출력되는 파형과 듀티비를 확인하 기위해 오실로스코프로 PWM 모듈을 측정하였다. 전 압이 On-Off 되는 한 주기를 기준으로 듀티비가 약 80 $\%$ 임을 확인할 수 있다. PWM 방식의 문제점 중에 노 이즈 문제가 발생하는데, 이는 인버터부에서 주파수와 출력전압 및 전류를 제어하기위해 반도체소자를 고주 파로 스위칭 시키기 때문인데 이로 인해 펄스 폭 변조 가 이루어지는 것이다. 고주파로 인해 생긴 노이즈를 해결하기위해 많은 연구가 진행되고 있는 것으로 알 고 있다(Fig. 5).

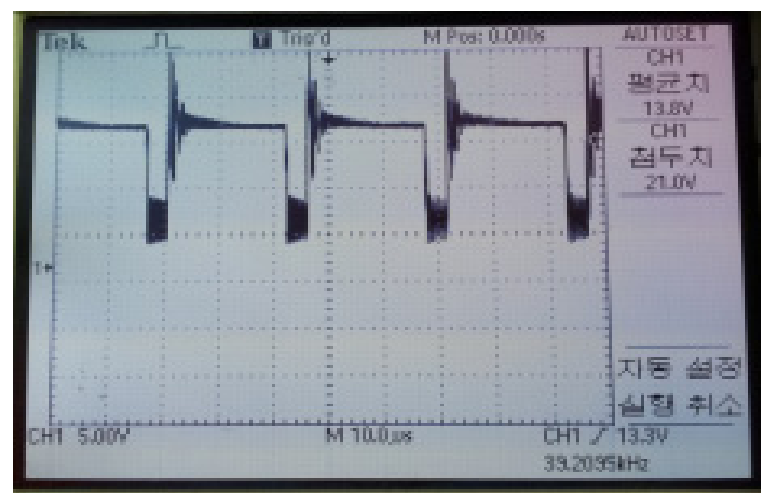

Fig 5. PWM output wave of PWM module

PWM 방식은 듀티비에 의해 평균전압을 낮춰주기
때문에 $1 \mathrm{~cm}^{2}$ 면적당 빛의 세기 $(\mathrm{W})$ 가 동일하게 나올 때 C.W 모드와 PWM 모드의 $\mathrm{LED}$ 출력전압 $(\mathrm{V})$ 을 측정 하였다(Fig. 6).

여드름 치료를 위해 고안한 실험으로 $660 \mathrm{~nm} 1 \mathrm{~W}$ $\mathrm{LED}$ 로 시스템 설계를 하였기에 빛의 최대 세기는 1 $\mathrm{W}$ 내로 나타났다.

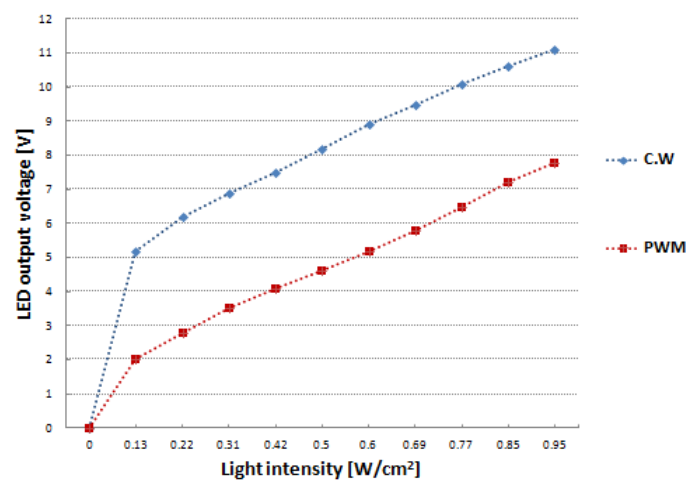

Fig 6. Comparison of LED output voltages between C.W mode and PWM mode for the same light intensity

$\mathrm{DC} 12 \mathrm{~V}$ 의 입력전압을 C.W 모드와 PWM 모드로 LED 모듈에 공급해주고 입력전류 값을 상승해가면서 빛의 세기 $(\mathrm{W})$, 출력전류(A) 그리고 출력전압(W)을 확 인했다. 그 결과 C.W 모드와 PWM 모드로 LED에 신 호를 주었을 때 $\mathrm{LED}$ 의 최소 빛의 세기 $(\mathrm{W})$ 는 두 가지 모드(C.W, PWM) 동일한 $0.13 \mathrm{~W}$ 였고, LED에 흐르는 전류 또한 두 모드 동일한 약 $3.5 \pm 0.2 \mathrm{~mA}$ 의 전류가 흘렀다. 이때 $\mathrm{LED}$ 에 흐르는 전압 $(\mathrm{V})$ 은 C.W 모드일 때 약 $5.2 \mathrm{~V}, \mathrm{PWM}$ 모드일 때는 약 $2 \mathrm{~V}$ 의 전압이 흘렀다. $\mathrm{LED}$ 의 최대 빛의 세기 $(\mathrm{W})$ 는 두 모드 $0.95 \mathrm{~W}$ 였고, $\mathrm{LED}$ 에 흐르는 전류 또한 두 모드가 동일한 약 $25.98 \pm$ $0.2 \mathrm{~mA}$ 였다. 그리고 C.W 모드일 때 LED에 흐르는 전 압은 약 $11.1 \mathrm{~V}$ 정도였고, PWM 모드일 때는 약 $7.8 \mathrm{~V}$ 전압이 $\mathrm{LED}$ 에서 측정되었다.

$\mathrm{LED}$ 빛의 세기(W)를 최소세기에서 최대세기까지 전류를 증가시키면서 측정한 결과 두 모드(C.W, PWM) 에서 선형적으로 빛의 세기가 증가하는 것을 보였고, $\mathrm{LED}$ 에 흐르는 전류 값과 빛의 세기는 동일하나 전압 차가 $\mathrm{PWM}$ 모드일 때 약 $3 \pm 0.3 \mathrm{~V}$ 정도 전압이 적게 필요로 했다. 이는 PWM에서 발생한 약 $80 \%$ 의 듀티 비로 인하여 약 $20 \%$ 정도의 전압이득을 본 셈이다. 


\section{$3.2 \mathrm{LED}$ 빛 에너지에 의한 생체조직 열적 반응}

$\mathrm{LED}$ 의 빛 에너지 $\left[\mathrm{J} / \mathrm{cm}^{2}\right]$ 에 의한 생체조직의 열적반 응을 실험하기위해 돼지고기의 목살(Jowl)에 C.W 모드 와 PWM 모드로 1초에 $0.95 \mathrm{~J} / \mathrm{cm}^{2}$ 씩 약 1100 초 동안 조사하였다(Fig. 7).

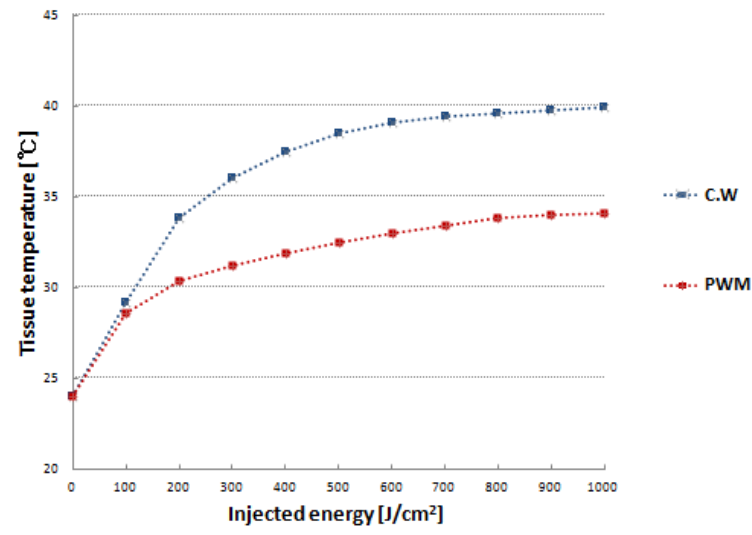

Fig 7. Tissue temperatures with each radiation mode

C.W 모드는 처음에 약 $37{ }^{\circ} \mathrm{C}$ 까지 급격한 온도상승 을 보이더니 그 이후부터는 온도가 천천히 증가하였 다. 1100 초 이후에도 온도상승률은 서서히 증가하는 경향을 보여 오랜 시간 빛에 노출되면 생체조직의 열 적 파괴현상을 가져올 경향이 나타났다.

$\mathrm{PWM}$ 모드는 처음에 약 $30{ }^{\circ} \mathrm{C}$ 까지 빠른 온도상승을 보였으나, $33{ }^{\circ} \mathrm{C}$ 부터는 온도가 거의 고정되는 경향을 보여 생체조직의 열적파괴현상이 발생할 우려가 나타 나지 않았다.

\section{IV. 고찰}

본 실험은 미래 광원으로 가장 각광받고 있는 LED 를 이용하여 의료분야에 적용하기위해 피부과 병변 중 여드름 치료에 많이 사용되고 있는 $\mathrm{Nd}: \mathrm{YAG}$ 레이 저와 IPL레이저의 치료원리를 기초로 하여 C.W 방식 과 PWM 방식으로 $\mathrm{LED}$ 를 이용한 여드름 치료 시 발 생할 수 있는 생체조직에서의 열적반응 현상과 에너 지효율에 대해 실험.연구를 하였다. 실험을 위하여 $\mathrm{PWM}$ 기반 광 조사 시스템을 설계하였으며, 사용한 광 학장치로는 피지생성을 억제하고 염증반응 소실 및
콜라겐 형성에 도움을 주는 $660 \mathrm{~nm} 1 \mathrm{~W} \mathrm{LED}$ 를 사용 하였다 ${ }^{[14]}$. PWM의 에너지 효율과 피부에서 반응하는 열적현상을 확인하기위해 C.W 방식과 비교하여 실험 을 진행하였다. C.W, PWM 모두 동일한 DC $12 \mathrm{~V}$ 의 전 원을 공급해주고 $\mathrm{LED}$ 빛의 최소세기와 최대세기일 때 전류 $(\mathrm{A})$ 값과 전압 $(\mathrm{V})$ 값을 측정하였으며 결과적으 로 C.W, PWM 모두 동일한 빛의 세기는 최소 0.13 $\mathrm{W} / \mathrm{cm}^{2}$ 에서 최대 $0.95 \mathrm{~W} / \mathrm{cm}^{2}$ 의세기를 나타내었으며 이때 LED에 흐르는 최소, 최대 전류(A) 값은 3.5 25.98 $\pm 0.2 \mathrm{~mA}$ 였다. 두 모드 빛의 세기(W)와 전류(A)는 커 다란 변화를 발견하지 못했지만 C.W 모드일 경우 $\mathrm{LED}$ 에 흐르는 전압은 빛의 세기에 비례하여 최소 5.2 $\mathrm{V}$ 에서 최대 $11.1 \mathrm{~V}$ 였고, $\mathrm{PWM}$ 모드일 경우는 최소 $2 \mathrm{~V}$ 에서 최대 $7.8 \mathrm{~V}$ 의 전압이 흘렀다. 이는 $\mathrm{PWM}$ 의 특징 인 듀티비에 의한 것으로 여드름 치료를 위해 설계한 광 조사 시스템의 듀티비는 약 $80 \%$ 정도였고 약 $20 \%$ 정도의 전압이득을 얻었다. 이 결과 C.W 방식보다 $\mathrm{PWM}$ 방식에서 적은 전압을 소모한다는 것을 확인하 였다. 생체조직의 열적반응에서는 C.W 모드로 돼지고 기 목살(Jowl)에 LED 빛을 조사하였을 경우 약 $37{ }^{\circ} \mathrm{C}$ 까지 급격한 온도상승을 보였고, $40{ }^{\circ} \mathrm{C}$ 가 넘었을 때도 지속적인 온도상승이 발생하였다. PWM 모드로 LED 빛을 조사하였을 때는 약 $30{ }^{\circ} \mathrm{C}$ 까지 빠른 온도상승을 보이다가 약 $33{ }^{\circ} \mathrm{C}$ 이상부터는 온도가 거의 고정되는 경향을 보였다. 결과적으로 $\mathrm{PWM}$ 방식을 사용하였을 경우 C.W 방식보다 약 $20 \%$ 적은 전력으로 동일한 빛 의 세기와 에너지를 얻을 수 있었으며, 생체조직의 열 적반응 실험에서는 약 $4{ }^{\circ} \mathrm{C}$ 의 적은 열과 안정적인 온 도상승으로 PWM 방식이 C.W 방식보다 생체조직의 열적현상에도 좋은 반응을 나타냈다. 하지만 스위칭 펄스의 폭을 변화시키기 위해 PWM에서 발생한 고주 파가 인체와 전력손실에 어떠한 영향을 미치는지는 더 많은 연구 및 실험이 이루어져야 된다고 본다. 본 논문은 여드름 치료를 위해 C.W 방식과 PWM 방식을 사용하였을 때 에너지 손실과 생체조직에서의 열적반 응에 대해 실험한 것으로 $660 \mathrm{~nm} 1 \mathrm{~W} \mathrm{LED}$ 와 같은 고 출력으로 여드름 치료 시 열에 약한 정상조직을 보호 할 수 있고 에너지 손실이 적어 PWM 방식을 사용하 는 것이 유용하다고 사료된다. 


\section{V. 결론}

기존의 여드름 치료에는 레이저나 C.W 방식의 400 $\mathrm{nm} \sim 420 \mathrm{~nm}$ 의 Blue light와 $635 \mathrm{~nm}$ 의 LED가 주로 사용 되어 왔으며 ${ }^{[15]}$, 레이저의 경우 치료 및 개발에 있어 높 은 비용발생과 순간적인 열로 인한 검은 딱지가 발생 되어 불편함이 있었다. 그리고 기존의 $\mathrm{LED}$ 의 경우 C.W 방식과 낮은 파장대역 으로 치료효과가 높지 못 했다. 이를 개선하고자 PWM을 활용한 $1 \mathrm{~W}$ 의 빛의 세 기와 $660 \mathrm{~nm}$ 파장의 $\mathrm{LED}$ 를 이용하여 제작된 시스템 으로 시스템 성능 및 생체조직에서의 열적현상을 실 험하여 다음과 같은 결과를 얻었다.

1. Timer 모듈, PWM 모듈, LED 광 모듈로 구성된 여드름 치료용 광 조사시스템을 설계하여 성능 평가 결과 $660 \mathrm{~nm}$ 파장대역과 $1 \mathrm{~W}$ 의 LED에서 실제 $0.95 \mathrm{~W}$ 의 광 출력이 발생되었다.

2. PWM 모듈은 오실로스코프를 이용하여 펄스파의 출력을 확인하였으며, 약 $80 \%$ 의 듀티비(Duty ratio)로 약 $20 \%$ 의 전압이득 그래프를 보였다.

3. C.W 방식과 PWM 방식 모두 DC $12 \mathrm{~V}$ 의 전원을 공급해주었을 때 빛의 세기는 $0.13 \sim 0.95 \mathrm{~W} / \mathrm{cm} 2$ 의 세 기로 동일하게 발생되었다.

4. 에너지 효율은 C.W 방식과 PWM 방식으로 LED 가 조사되고 있을 시 $\mathrm{LED}$ 에 흐르는 전압을 측정하였 으며, C.W 방식일 경우 빛의 세기에 비례하여 최소, 최대 5.2 11.1 V의 전압이 측정되었고, $\mathrm{PWM}$ 일 경우 $2 \sim 7.8 \mathrm{~V}$ 의 전압이 측정되어 약 $3 \pm 0.3 \mathrm{~V}$ 의 전압이득으 로 에너지 효율 향상을 보였다.

5. 제작된 광 조사 시스템으로 생체조직(돼지고기 목살)에서의 열적반응을 1 초에 $0.95 \mathrm{~J} / \mathrm{cm}^{2}$ 씩 약 1100 초 동안 조사하여 그래프로 나타낸 결과 C.W 모드일 경우 $37{ }^{\circ} \mathrm{C}$ 까지 급격한 온도상승과 그 이후에도 지속 적 온도상승이 발생하였으며, PWM 모드 일 경우는 33 ${ }^{\circ} \mathrm{C}$ 까지 온도상승 후 고정된 온도상승을 보여 정상조 직에서 열적손상의 우려가 나타나지 않았다.

위와 같은 결과로 본 실험 논문을 위해 개발된 $\mathrm{PWM}$ 을 활용한 여드름 치료용 광 조사시스템을 여드 름 치료를 목적으로 이용할 수 있을 것으로 사료되며,
PWM 방식이 C.W 방식보다 여드름 치료에 효과적이 라 본다. 또한 탈모 치료, 세포의 신진대사 및 면역체 계의 자극효과를 발휘하여 의료기기로서의 적용가능 범위를 높일 수 있을 것으로 본다.

\section{참고문헌}

[1] 임현수, "광역학적 암진단을 위한 광원 장치의 설계 및 평가", 대한전기학회, ICS07 정보 및 제어 심포지움 논문집, 2007.

[2] Carl. D, "Update on photodynamic therapy", Curr. Opin Opthalmol, Vol. 11, pp.166-170, 2000.

[3] Rzany B, Kahl C, "Epidemiology of vulgaris", J Dtsch Dermatol Ges, Vol. 4, pp.4-9, 2006.

[4] Xiaoru Xu, Xiaobo Wu, "High Dimming Ratio LED Driver with Fast Transient Boost Converter", Power Electronics Specialists Conference, IEEE, pp.4192-4195, 2008.

[5] Heffernan B, Frater L, Watson N, "LED replacement for fluorescent tube lighting", Power Engineering Conference, AUPEC 2007, Australasian Universities, pp.1-6, 2007.

[6] K. Kalka, H. Merk, H. Mukhtar, "Photodynamic Therapy in Dermatology," J. Am.Acad. Dermatol., Vol. 42, pp.389-413, 2000.

[7] Elman M, Lebzelter J, "Light therapy in the treatment of acne vulgaris", Dermatol Surg, Vol. 30, pp.139-146, 2004.

[8] Zane C, Capezzera R, Pedretti A, Facchinerri E, Calzavarapinton $\mathrm{P}$, "Non-invasive diagnostic evaluation of phototherapeutic effects of red light phototherapy of acne vulgaris", Photodermatol Photomed, Vol. 24, pp.244-248, 2008.

[9] M.R Hamblin, T.N Demidova, "Mechanisms for Low light Therapy", Proc. SPIE, Vol. 6140, pp.1-12, 2006.

[10] L.Svilainis, "LED PWM dimming Linearity investigation Display", pp.243-249, 2008.

[11] M. Day, "TLC5940 PWM dimming provides superior color quality in LED video displays", Analog Applications Journal, 2006.

[12] 홍창희, “고출력 LED의 신기술 동향 및 응용”, 한국 조명·전기설비 학회, 2004 춘계학술대회 조명분야 전문 워크샵, pp.39, 2004.

[13] 임현수, "광역학적 암치료와 레이저의 응용", 궁미디어, pp.80-81, 2010.

[14] Aimbire F, Albertini R, Pacheco MT, Castro-Faria-Neto HC, Leonardo PS, Iversen VV, "Low-level laser therapyinduces 
dose-dependent reduction of TNF alpha levelsin acute inflammation", Photomed Laser Surg, Vol. 24, pp.33-37, 2006.

[15] Na JI, Suh DH, "Red light phototherapy alone is effectivefor acne vulgaris: randomized, single-blinded clinical trial", Dermatol Surg, Vol. 33, pp.1228-1233, 2007. 